DOI: https://doi.org/10.32838/2523-4803/70-2-48

УДК 658.012 .12

Чузрій Г.А.

завідувач відділу технологій виробництва сільськогосподарської продукції, Донецька державна сільськогосподарська дослідна станція НААН України

\title{
Chuhrii Hanna
}

Donetsk State Agricultural Science Station of NAAS of Ukraine

\section{СУТНІСТЬ ТА РОЛЬ СТРАТЕГІЧНОГО АНАЛІЗУ В СИСТЕМІ УПРАВЛІННЯ ПІДПРИЄМСТВОМ}

У статті розкрито сутність стратегічного аналізу управління підприємствами. Представлено підходи науковиів до визначення поняття «стратегічне управління». Доведено, шуо головним значенням в управлінні стратегічним аналізом є иіль підприємства, розроблено матрицю суперечності иілей. Визначено, щзо стратегічний аналіз сприяє реалізації мети управління, щзо пов 'язано з пошуком иляхів забезпечення виконання господарською одиницею своєї місії, иілей та стратегій, розробленням і забезпеченням виконання планів як інструментів з удосконалення підприємства та його окремих підсистем. Доведено, шзо поняття оиінки необхідності стратегічного аналізу в ефективному управлінні - ие системне, комплексне, органічно взаємозв'язане дослідження чинників зовнішнього та внутрішнього середовища, які впливають на економічні перспективи господарської одиниці. Розроблено деталізацію місії підприсмства із застосуванням стратегічних карт. Визначено приниипи стратегічного аналізу. Доведено, щзо використання методів і прийомів стратегічного аналізу сприятиме розробленню науково обтрунтованих оптимальних управлінських рімень. Запропоноване визначення поняття стратегічного аналізу сприятиме його системній інтеграції з вимогами стратегічного управління і створить передумови для впровадження ефективного управління підприємством.

Ключові слова: стратегічний аналіз, стратегічне управління, мета, місія, приниипи стратегічного аналізу, концеепиія.

Постановка проблеми. Для зміцнення свого становища на ринку, забезпечення координації зусиль, успішної конкуренції та досягнення глобальних цілей кожна сільськогосподарська одиниця має запроваджувати якісну систему управління, зокрема стратегічного, яка здатна забезпечити іiї функціонування в довгостроковій перспективі шляхом установлення динамічного балансу з оточенням, відстеження й адаптації до змін в оточенні, пошуку нових можливостей у конкурентній боротьбі.

Стратегічний аналіз - це процес, який дає змогу узагальнити позицію підприємства та конкретизувати напрями його розвитку на перспективу.

Складність процесу стратегічного аналізу в управлінні підприємством визначається орієнтацією на довгострокову перспективу, своєчасністю, адекватністю і точністю реакції господарської одиниці на нові запити ринку та на зміни в оточенні, невизначеністю середовища й наявністю багатьох критеріїв вибору, національними державними інтересами, з одного боку, та дією імперативів розвитку світового співтовариства - 3 іншого, зростанням інтенсивності конкуренції, масштабністю процесу дослідження. Отже, стратегічне управління - це концепція ефективного управління підприємством, яка здатна забезпечити йому довгострокове існування за умов динамічного зовнішнього середовища та невизначеності майбутнього [4, с. 935; 7, с. 34].
Аналіз останніх досліджень і публікацій. Проблеми стратегічного управління сільськогосподарськими підприємствами останнім часом привертають увагу багатьох учених-економістів, серед яких: В.І. Блонська, С.М. Божко, Ю.Г. Бондаренко, О.Д. Гудзинський, О.С. Даневич, О.М. Дмитренко, В.Я. Заруба, Б.М. Мізюк, Б.І. Шелегеда та ін. Разом із тим невирішеною залишається низка актуальних питань організаційно-економічного плану щодо стратегічного управління аграрними підприємствами [3, с. 46].

Праці зарубіжних авторів присвячено систематизації знань про різні методи і моделі стратегічного бізнес-аналізу. Дослідження вітчизняних учених стосуються прикладних аспектів стратегічного аналізу. Однак розроблені ними методики стратегічного аналізу залишаються незатребуваними, бо на вітчизняних підприємствах стратегічне управління запроваджується дуже повільно.

Вагомий внесок у розроблення проблем, що пов'язані з формуванням стратегії та цілей підприємства, зробили такі вчені: I. Ансофф, В. Герасимчук, В. Гончаров, П. Друкер, Т. Коно, О. Кузьмін, М. Мескон, А.А. Пилипенко, В. Стадник, М. Тимощук, Р. Фещура, В. Шатун, А. Шегда та ін.

Формулювання цілей статті. Метою статті $\epsilon$ обгрунтування основних вихідних положень теорії й ролі стратегічного аналізу, які зумовлюються запитами сучасного ефективного управління. 
Виклад основного матеріалу. Стратегічний аналіз підприємства являє собою багаторівневе дослідження зовнішнього і внутрішнього середовища стратегічного потенціалу підприємства, їх взаємодії для визначення стратегічної орієнтації, на основі якої формується стратегія управління підприємством.

3 погляду наукового аспекту проблеми вченими не досягнуто єдності в розумінні сутності стратегічного аналізу та його об'єктивної необхідності.

М.І. Баканов, М.В. Мельник, А.Д. Шеремет уважають, що, по-перше, під час виокремлення видів економічного аналізу про стратегічний аналіз не згадують узагалі. По-друге, відбувається ототожнення понять стратегічного і перспективного аналізу, де перспективний аналіз розглядає процеси господарської діяльності з позиції майбутнього, тобто перспективи розвитку, з погляду проекцій складових елементів минулої й теперішньої господарської діяльності в елементи майбутньої [1].

По-третє, у фаховій літературі в трактуванні його сутності немає консенсусу серед дослідників. Так, М.І. Баканов, М.В. Мельник, А.Д. Шеремет уважають, що стратегічний аналіз - це комплексне дослідження позитивних і негативних чинників, які можуть вплинути на економічне становище підприємства у перспективі, а також шляхів досягнення стратегічних цілей підприємства $[1 ; 2]$.

Є.В. Мних та Т.С. Муляр зазначали: «Стратегічним економічним аналізом називають дослідження економічної системи за параметрами, які визначають iіi майбутній стан». Інші вчені наголошують на тому, що стратегічний аналіз застосовуються для з'ясування основних довгострокових тенденцій і чинників розвитку господарської діяльності [6, с. 7; 7, с. 36-40].

Отже, під час формулювання сутності стратегічного аналізу необхідно виходити 3 того, що він $є$ функцією управління і має сприяти реалізації його мети - пошуку шляхів забезпечення виконання господарською одиницею своєї місії, цілей та стратегій, розроблення і забезпечення виконання системи планів як інструментів з удосконалення підприємства та його окремих підсистем.

Таким чином, спираючись на об'єктивну оцінку, необхідність стратегічного аналізу в ефективному управлінні - це системне, комплексне, органічно взаємозв'язане дослідження чинників зовнішнього i внутрішнього середовища, що впливають на економічні перспективи господарської одиниці щодо обгрунтування місії, цілей, формування ефективних стратегій i розроблення системи планів як інструменті досягнення стратегічних орієнтирів.

Головним в управлінні стратегічним аналізом $€$ ціль підприємства - це описані у формалізованому вигляді межі, яких підприємство бажає досягти в довго- й короткостроковому періодах.

Діяльність підприємства об'єктивно дуже різноманітна, тому підприємство не може бути зосереджене на єдиній меті, а повинно виділити ключові сфери, у рамках яких слід визначати свої цілі. Численні цілі підприємства можуть бути об'єднані в дві групи: економічного і неекономічного характеру.

Неекономічні цілі переважно пов'язані із соціальними завданнями підприємства. Формулювання соціальних цілей $\epsilon$, безумовно, важливим завданням, адже комерційне підприємство - це не просто ділова структура, орієнтована на отримання прибутку, а й об’єднання людей, що мають певні потреби.

Окрім того, потрібно враховувати соціальну відповідальність підприємства перед суспільством, що може виражатися в таких цілях, як створення додаткових робочих місць, надання добродійної допомоги, прийняття на роботу інвалідів, молодих людей та ін.

Економічні цілі підприємства виражаються в показниках господарської діяльності і можуть бути кількісними або якісними. Наприклад, кількісна мета збільшення обсягу продажів на $15 \%$ до 2022 р., якісна мета - досягнення організацією технологічного лідерства в галузі.

Розробимо матрицю цілей, які ставить перед собою сільськогосподарське підприємство. На рис. 1 представлено приклад можливих цілей та їх поєднання. Цілі різноманітні, їх поєднання не такі очевидні. Проте на етапі постановки мети завжди необхідно аналізувати цілі, що заявляються, на предмет можливості їх сумісного досягнення.

На перехресті цілей знаком «+» позначено пари цілей, які $є$ комплементарними або можуть сприятливо поєднуватися одна 3 одною. Знаком «?» позначено пари цілей, взаємне досягнення яких неоднозначно. Навхрест перекреслені цілі, взаємне досягнення яких $\epsilon$ проблематичним.

Для організації діяльності підприємства істотними $\epsilon$ часові характеристики цілей. Якщо підприємство орієнтується на довгострокові цілі, можна затверджувати про доцільність створення системи стратегічного управління.

Довгострокові цілі точно визначають бажані результати і ринкову позицію 3 урахуванням досягнутого рівня розвитку на даний момент.

Короткострокові цілі точно визначають найближчі конкретні організаційні цілі й ринкову позицію, яку організація бажає зайняти, враховуючи довгострокові цілі організації. Для реалізації місії підприємства та досягнення генеральної мети потрібно довести їх зміст до кожного рівня і виконавця, визначити внесок кожного 3 працівників у стратегічний успіх підприємства взагалі.

Для реалізації місії підприємства треба розробити стратегічну карту. Процес розроблення стратегічних карт наочно представлено на рис. 2.

Місія компанії - уявлення підприємства про своє майбутнє. Мета розроблення місії полягає у керівництві, контролі й мотивації просування компанії як єдиного цілого до реалізації поставлених і узгоджених цілей.

Ключові аспекти діяльності. Після того як корпоративна місія сформульована і розроблена модель бізнесу, можна переходити до аналізу окремих аспек- 


\begin{tabular}{|c|c|c|c|c|c|c|}
\hline $\begin{array}{c}\text { Завдання } \\
\text { ЗБІЛЬШИТИ }\end{array}$ & $\begin{array}{c}\text { Валовий } \\
\text { дохід }\end{array}$ & $\begin{array}{c}\text { Обсяг } \\
\text { продажів }\end{array}$ & Прибуток & $\begin{array}{c}\text { Рентабельність } \\
\text { продажів }\end{array}$ & $\begin{array}{c}\text { Акціонерний } \\
\text { капітал }\end{array}$ & $\begin{array}{c}\text { Ринкову } \\
\text { частку }\end{array}$ \\
\hline $\begin{array}{c}\text { Рентабельність } \\
\text { капіталу }\end{array}$ & $?$ & $?$ & + & + & & \\
\hline Ринкову частку & + & + & + & $?$ & & \\
\hline $\begin{array}{c}\text { Акціонерний } \\
\text { капітал }\end{array}$ & $?$ & $?$ & + & + & & \\
\hline
\end{tabular}

Рис. 1. Матриця суперечності цілей

Джерело: розроблено автором

Місія

У чому полягає місія компанії в майбутньому?

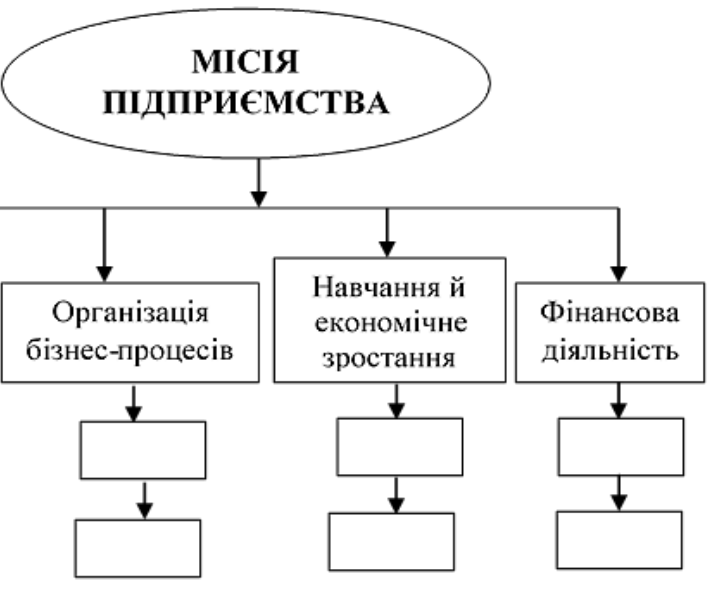

Ключові чинники успіху

Які ключові чинники успіху для досягнення поставлених цілей?

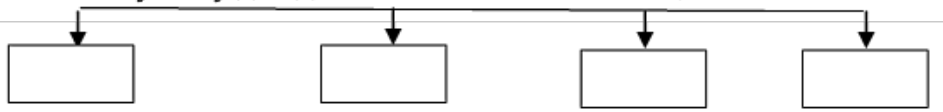

Показники для оцінки ступеня досягнення стратегічних цілей

Яка система показників зможе адекватно відобразити стратегічний напрям розвитку компанії?

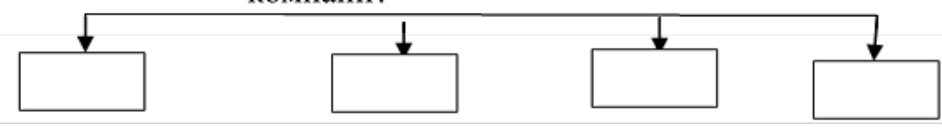

План заходів

Які заходи необхідно провести, щоб добитися успіху?

Рис. 2. Деталізація місії підприємства із застосуванням підходу стратегічних карт

Джерело: розроблено автором

тів діяльності компанії, відібравши ті з них, для яких розроблятимуться стратегічні карти. Найчастіше до них належать фінансова діяльність і взаємини з власниками, відносини зі споживачами, внутрішня організація бізнесу, навчання й розвиток.

Стратегічні изілі. Місія підприємства представлена у вигляді сукупності конкретних стратегічних цілей діяльності. Завдання цього етапу - перевести узагальнену місію підприємства на більш практичний рівень, забезпечивши баланс між довгостроковими i короткостроковими цілями, для чого й призначені стратегічні карти.
План дій. Нарешті, завершує стратегічну карту розділ, що описує етапи і конкретні дії, що робляться для реалізації поставлених завдань та місії підприємства. План заходів повинен також передбачати відповідальних за виконання конкретних заходів і терміни проміжних і підсумкових звітів.

Отже, стратегічні карти не гарантують вироблення успішної місії й стратегії підприємства, проте саме їх розроблення й упровадження вже дають йому чималі переваги. Упровадження цієї моделі є ефективним способом деталізації місії і стратегії підприємства в зрозумілому вигляді. 
«Дерево цілей» - це наочне графічне зображення підлеглості і взаємозв'язку цілей, який демонструє розподіл загальної (генеральної) мети або місії на підцілі, завдання й окремі дії.

Ступінь кількісної визначеності цілей дає можливість вибрати відповідні методи аналізу і побудови «дерева цілей», що дуже важливо для подальшої організації діяльності підприємства.

Метод забезпечення необхідних умов під час побудови «дерева цілей» можна використовувати для декомпозиції цілі будь-якого типу. Цей метод передбачає, що сформульована генеральна мета пропонується експертам для аналізу і побудови «дерева цілей».

На основі наших досліджень можна сказати, що в процесі стратегічного аналізу реалізуються три основні функції: оціночна, діагностична, пошукова.

Провідні спеціалісти у сфері стратегічного менеджменту стверджують, що метою стратегічного аналізу $є$ збір інформації $[10 ; 11]$. Незаперечним є той факт, що в процесі аналізу дослідження об'єктів здійснюється через систему інформації, тому початковою стадією процесу пізнання є формування системи показників, яка релевантно характеризує об'єкт і в процесі аналі-

\section{Принципи стратегічного аналізу}

Таблиця 1

\begin{tabular}{|c|c|}
\hline Назва & Характеристика \\
\hline $\begin{array}{l}\text { Принцип системного } \\
\text { підходу }\end{array}$ & $\begin{array}{l}\text { Один із базових принципів стратегічного аналізу. Він забезпечує більші можливості у пізнанні, } \\
\text { створюючи передумови механізму цілісності пізнання об’єкта, що складається з елементів, } \\
\text { яким властиві внутрішньосистемні зв'язки, кожен із яких має свої цілі, а також взаємозв'язки } \\
\text { внутрішнім середовищем. }\end{array}$ \\
\hline $\begin{array}{l}\text { Принцип комплексного } \\
\text { підходу }\end{array}$ & $\begin{array}{l}\text { Передбачає, що всі досліджувані проблеми мають розглядатися в комплексі. Практично кожна } \\
\text { ситуація породжена системою факторів, тому за формами прояву своїх негативних наслідків має } \\
\text { комплексний характер. Аналогічний характер повинна мати й система заходів, яка розробляється } \\
\text { в процесі стратегічного аналізу з метою нейтралізації негативного впливу чинників та їхніх } \\
\text { негативних наслідків і коригування системи планів, стратегій і цілей. Комплексний підхід } \\
\text { визначає організаційну і методологічну послідовність у проведенні стратегічного аналізу: } \\
\text { організаційна - передбачає логічну послідовність у дослідженні, методологічна - поетапне } \\
\text { проведення стратегічного аналізу. }\end{array}$ \\
\hline $\begin{array}{l}\text { Програмно-цільовий } \\
\text { підхід }\end{array}$ & $\begin{array}{l}\text { Організація аналітичного дослідження спрямовується на досягнення визначеної мети } 3 \\
\text { урахуванням оптимального використання ресурсів зазаданих обмежень. Ефективність досягненн } \\
\text { цілей залежить від правильної інтеграції генеральної цілі з індивідуальними (відсутність навіть } \\
\text { одного складника робить ціль нереалізованою). Програмно-цільовий підхід дає змогу в комплексі } \\
\text { вивчити всі елементи системи у взаємозв’язках і взаємозалежності, у підпорядкуванні їх головній } \\
\text { меті на всіх рівнях управління, всіма службами підприємства, синтезувати елементи у підцілі. }\end{array}$ \\
\hline Інтегральний підхід & $\begin{array}{l}\text { Спрямований на дослідження іпосилання взаємозв'язків між окремимипідсистемами й елементами } \\
\text { стратегічного аналізу. Реалізація цього принципу забезпечує конкретизацію взаємозв'язків між } \\
\text { ними, робить процес прийняття управлінських рішень цілеспрямованим. При цьому проблема } \\
\text { розглядається як єдина система, у межах якої виявляються результати кожного часткового рішення } \\
\text { окремого рівня управління, вивчаються можливі варіанти досягнення цілей. Керівництво вищого } \\
\text { рівня має бачити перспективу розвитку підприємства, чітко уявляти, як пов'язанні між собою } \\
\text { структурні підрозділи та вплив кожного з них на досягнення мети, як зміни, що відбуваються в } \\
\text { одній частині системи, впливають на стан іншої, тобто прямі і зворотні зв'язки. }\end{array}$ \\
\hline Ситуаційний підхід & $\begin{array}{l}\text { Грунтується на виборі методів аналітичного дослідження, який визначає конкретну ситуацію. Одна } \\
\text { й та сама стратегія залежить від часу дослідження, непередбачених обставин, потребує різних } \\
\text { шляхів її дослідження, тобто різного плану реалізації. Тому програма аналітичного дослідження } \\
\text { має бути гнучкою, адаптованою до зміни ситуації. Ситуаційний підхід допомагає узгодити } \\
\text { конкретні прийоми й концепції з визначеними конкретними ситуаціями для досягнення цілей. }\end{array}$ \\
\hline Принцип невизначеності & $\begin{array}{l}\text { Декларує врахування невизначеносте і випадковостей у системі, які виникають унаслідок } \\
\text { недостатньої кількості інформації, що характеризує конкретний фактор зовнішнього оточення, а } \\
\text { також невпевненості і достовірності інформації (майбутнє завжди є невизначеним). }\end{array}$ \\
\hline Принцип безперервності & $\begin{array}{l}\text { Полягає у тому, що процес зміни потенціалу системи та її оточення йде безперервно, змінюється } \\
\text { лише швидкість зміни. Виходячи із цього принципу, американськими вченими А.А. Томпсоном } \\
\text { та А.Дж. Стріклендом доведено, що стратегічний менеджмент - це неперервний і нескінчений } \\
\text { процес, а не якийсь одноразовий захід, виконавши який можна спокійно займатися іншими } \\
\text { справами }[9, \text { с. } 117] \text {. Це вимагає постійного стратегічного аналізу змін зовнішнього та } \\
\text { внутрішнього середовища для визначення цілей господарської одиниці, розроблення стратегій і } \\
\text { їх реалізації та контролю над процесом виконання. }\end{array}$ \\
\hline Принцип адаптивності & $\begin{array}{l}\text { Чинники, які характеризують зовнішнє і внутрішнє оточення господарської одиниці, } \\
\text { характеризуються високою динамічністю. Це визначає необхідність гнучкості методології } \\
\text { стратегічного аналізу, їі швидкої адоптації до зміни умов середовища. }\end{array}$ \\
\hline Принцип ефективності & $\begin{array}{l}\text { Реалізація цього принципу забезпечує зіставлення ефекту стратегічного аналізу і витрат на його } \\
\text { організацію та проведення. Крім того, ефект аналізу може визначитися розробленням ефективних } \\
\text { стратегій, які забезпечують досягнення цілей. }\end{array}$ \\
\hline
\end{tabular}

Джерело: розроблено на основі [5, с. 18-20] 
тичної обробки забезпечує формулювання об'єктивних аналітичних висновків, що дасть змогу прийняти виважені управлінські рішення.

Установлено, що стратегічний аналіз як функція стратегічного управління має вирішити основне завдання підготовка множини альтернатив для прийняття рішень, орієнтованих на перспективу. Це завдання дуже проблематичне, оскільки в умовах невизначеності вибір альтернатив та їх належне аналітичне обгрунтування $€$ складною процедурою, вимагає глибокого системного дослідження фактів і явищ із метою формування чинників та критеріїв для проведення досліджень і здійснення оцінки стратегій діяльності на їх основі.

За допомогою стратегічного аналізу досліджуються взаємозалежності між середовищем і господарською одиницею, що дає можливість максимально звузити поле пошуку дії чинників негативного впливу, створюються передумови діагностики структурних елементів, зовнішнього та внутрішнього середовища, що знаходяться під негативним впливом. Цей вид аналізу можна віднести до системного.

Системний аналіз - науковий метод пізнання, що являє собою послідовність дій $з$ установлення структурних зв'язків між змінними або елементами досліджуваної системи. Спирається на комплекс загальнонаукових, експериментальних, природничих, статистичних, математичних методів.

Системний аналіз використовується для поглибленого втручання в проблемні ситуації стратегічного управління. Його конструктивність пояснюється тим, що методи стратегічного аналізу грунтуються на визначенні закону функціонування системи виходячи з місії та мети господарської одиниці, формуванні варіантів структури системи і виборі найефективнішого варіанта, що здійснюється шляхом розв'язання задач декомпозиції, аналізу й синтезу досліджуваної системи.

Сучасні підходи до стратегічного аналізу випливають 3 ефективного управління, тому, безперечно, важливими є його внутрішня скоординованість і підпорядкованість загальним правилам. Виходячи із цього, першочергового значення набуває визначення й коректне застосування принципів стратегічного аналізу як основного вихідного положення його теорії та ролі, що визначає сутність і основу аналітичного процесу, регулює процедурний бік та методики стратегічного аналізу й забезпечує прийняття науково обгрунтованих управлінських рішень [5, с. 13].

Результати досліджень свідчать, що досягнення мети стратегічного аналізу потребує реалізації такої концепції, в якій поєднуються принципи: системного, комплексного, інтегрального підходів; безперервності; адаптивності; невизначеності та ефективності (табл. 1).

Використання вищезазначених методів і прийомів аналізу сприятиме розробленню науково обгрунтованих оптимальних управлінських рішень.

Висновки. Таким чином, запропоноване визначення поняття стратегічного аналізу сприятиме його системній інтеграції з вимогами стратегічного управління і створить передумови для впровадження ефективного управління підприємством.

\section{Список літератури:}

1. Баканов М.И., Мельник М.В., Шеремет А.Д. Теория экономического анализа / по ред. М.И. Баканова ; 5-е изд., перераб. и доп. Москва : Финансы и статистика, 2006. 536 с.

2. Бутинець Ф.Ф. Економічний аналіз : навчальний посібник. Житомир : Рута, 2003. 680 с.

3. Вінюкова О.Б., Чугрій Г.А. Особливості стратегічного управління розвитком аграрних підприємств Донецької області. Інфраструктура ринку. 2018. № 20. С. 46-49.

4. Ковальчук Т.М. Стратегічний аналіз фінансового потенціалу підприємства. Економіка і суспільство. 2016. № 7. C. 933-938.

5. Ковальчук Т.М. Аналіз як функція управління: теорія та методологія. Економіка АПК. 2009. № 12. С. 14-21.

6. Муляр Т.С. Впровадження стратегічного підходу в управління аграрними підприємствами. Агросвіт. 2015. № 4(1). C. 7-10.

7. Мних С.В. Економічний аналіз : підручник ; 2-е вид., перероб. і доп. Київ : Центр навчальної літератури, 2005.472 с.

8. Редченко К.І. Стратегічний аналіз в бізнесі : навчальний посібник. Львів : Новий світ, 2003. 272 с.

9. Томпсон А.А., Стрикленд А.Дж. Стратегический менеджмент. Искусство разработки и реализации стратегии / пер. с англ. под ред. Л.Г. Зайцева, М.И. Соколовой. Москва : Банки и биржи ; ЮНИТИ, 1998. 576 с.

10. Crozier M., Friberg E., Czlowiek i system. Ograniczenie dziafania zespotowego. PWE. Warszawa, 1982.386 s.

11. Pearce J.A. Strategic Management. Chicago : Homewood, 1985. P. 116.

\section{References:}

1. Bakanov M.I., Mel’nik M.V., Sheremet A.D. (2006) Teoriya e konomicheskogo analiza [Theory of economic analysis] 5-e izd. pererab. i dop. Moskva: Finansy $i$ statistika, p. 536.

2. Butynytsia F.F. (1999) «Ekonomichnyi analiz» [Economic analysis]. Zhytomyr: Ruta, p. 30.

3. Viniukova O.B., Chuhrii H.A. (2018) Osoblyvosti stratehichnoho upravlinnia rozvytkom ahrarnykh pidpryiemstv Donetskoi oblasti [Features of strategic management of development of agrarian enterprises of Donetsk region] Infrastruktura rynku: elektronnyi naukovo-praktychnyi zhurnal no. 20, p. 46-49

4. Kovalchuk T.M. (2016) Stratehichnyi analiz finansovoho potentsialu pidpryiemstva [Strategic analysis of the financial potential of the enterprise] Ekonomika i suspilstvo, no. 7, p. 933-938. 
5. Kovalchuk T.M. (2009) Analiz yak funktsiia upravlinnia: teoriia ta metodolohiia [Analysis as a Function of Management: Theory and Methodology] Mizhnarodnyi naukovo-vyrobnychyi zhurnal Ekonomika APK, no. 12, p. 14-21.

6. Muliar T.S. (2015) Vprovadzhennia stratehichnoho pidkhodu v upravlinnia ahrarnymy pidpryiemstvamy [Implementation of strategic approach in management of agricultural enterprises] Ahrosvit, no. 4 (1). p. 7-10.

7. Mnykh Ye.V. (2005) Ekonomichnyi analiz [Economic analysis] Tsentr navchalnoi literatury, p. 40.

8. Redchenko K.I. (2003) Stratehichnyi analiz v biznesi [Strategic analysis in business.] Novyi svit, p. 38.

9. Tompson A.A., Stryklend A. Dzh. (1998) Stratehycheskyi menedzhment. Yskusstvo razrabotky y realyzatsyy stratehyy [Strategic Management. The art of strategy development and implementation]. Moskva : Banky y byrzhy ; YuNYTY, p. 117. 10. Crozier M., Friberg E. (1982) Czlowiek i system. Ograniczenie dziafania zespotowego. PWE. Warszawa, p. 386.

11. Pearce J.A. (1985) Strategic Management. Chicago: Homewood, p. 116.

\section{СУЩНОСТЬ И РОЛЬ СТРАТЕГИЧЕСКОГО АНАЛИЗА В СИСТЕМЕ УПРАВЛЕНИЯ ПРЕДПРИЯТИЕМ}

В статье раскрыта сущность стратегического анализа управления предприятиями. Представлены подходы ученых к определению понятия «стратегическое управление». Доказано, что главным в управлении стратегическим анализом является иель предприятия, разработана матрица противоречия иелей. Определено, что стратегический анализ способствует реализации иели управления, связанной с поиском путей обеспечения выполнения хозяйственной единицей своей миссии, иелей и стратегий, разработкой и обеспечением выполнения планов как инструментов по совершенствованию предприятия и его отдельных подсистем. Доказано, что понятие оценки необходимости стратегического анализа в эффективном управлении - это системное, комплексное, органически взаимосвязанное исследование факторов внешней и внутренней среды, которые влияют на экономические перспективы хозяйственной единицы. Разработана детализаџия миссии предприятия с применением стратегических карт. Определены приничиы стратегического анализа. Доказано, что использование методов и приемов стратегического анализа будет способствовать разработке научно обоснованных оптимальных управленческих решений. Предложенное определение понятия стратегического анализа будет способствовать его системной интеграции с требованиями стратегического управления и создаст предпосылки для внедрения эффективного управления предприятием.

Ключевые слова: стратегический анализ, стратегическое управление, цель, миссия, принщипы стратегического анализа, конщепџия.

\section{ESSENCE AND ROLE OF STRATEGIC ANALYSIS IN THE ENTERPRISE MANAGEMENT SYSTEM}

It is proved that in order to strengthen its market position, ensure coordination of efforts, successful competition and achieve global goals, each agricultural unit has to introduce a quality management system, in particular strategic, which can ensure its functioning in the long term by establishing a dynamic balance with the environment, tracking and adaptation to changes in the environment, the search for new opportunities in the competition. The questions of substantiating the essence and role of strategic analysis are identified, which are stipulated by the demands of modern effective management. It is proved that strategic analysis is a management function and should contribute to the realization of its goal - the search for ways to ensure that the business unit fulfills its mission, goals and strategies, develop and enforce the system of plans as tools for improving the enterprise and its individual subsystems. The circle of the main problems faced by domestic scientific institutions is determined. They include that over the years of research from the point of view of the scientific aspect, unity has not been achieved in understanding the essence of strategic analysis and its objective necessity. The basic concept of "assessing the need for strategic analysis in effective management" is defined - this is a systematic, comprehensive, organically interconnected study of environmental and internal factors that affect the economic prospects of the unit to justify the mission, goals, the formation of effective strategies and the development of a system of plans as a tool for achieving strategic guidelines. The results of the author's research indicate that achieving the goal of strategic analysis requires the implementation of a concept that combines the following principles: systemic; complex; integrated approaches; continuity; adaptability; uncertainty and efficiency. It is proved that the use of methods and techniques of strategic analysis will contribute to the development of scientifically sound optimal management decisions. The proposed definition of the concept of strategic analysis will contribute to its system integration with the requirements of strategic management and will create the prerequisites for the implementation of effective enterprise management.

Key words: strategic analysis, strategic management, goal, mission, principles of strategic analysis, concept. 